\title{
Tobacco smoking and dopaminergic function in humans: a meta-analysis of molecular imaging studies
}

\author{
Abhishekh H. Ashok ${ }^{1,2,3}$ (D) $\cdot$ Yuya Mizuno ${ }^{3,4}$. Oliver D. Howes ${ }^{1,2,3}$ \\ Received: 6 December 2018 / Accepted: 7 February 2019 / Published online: 18 March 2019 \\ (C) The Author(s) 2019
}

\begin{abstract}
Rationale About 1.1 billion people smoke tobacco globally and tobacco-related health care costs $1.8 \%$ of GDP in many countries. The majority of people are unable to quit smoking despite pharmacological intervention, highlighting the need to understand the pathophysiology associated with tobacco smoking to aid the development of new therapeutics. The reinforcing effects of tobacco smoking are thought to be mediated by the dopamine system. However, the nature of dopamine dysfunction seen in smokers is unclear.

Objective To determine the nature and robustness of the evidence for dopaminergic alterations in smokers.

Methods The entire MEDLINE, EMBASE, and PsycINFO databases were searched for studies from inception date to November 18, 2018. In vivo human molecular imaging studies of dopamine measures (dopamine synthesis or release capacity, transporter levels, receptor levels) in tobacco smokers were selected. Demographic, clinical, and imaging measures were extracted from each study and meta-analyses, and sensitivity analyses were conducted.

Results Fourteen studies met inclusion criteria comprising a total sample of 219 tobacco smokers and 297 controls. The metaanalysis showed a significant reduction in dopamine transporter availability in the smokers relative to controls with an effect size of -0.72 ([95\% CI, -1.38 to -0.05$], p=0.03$ ). However, there was no difference in D2/3 receptor availability in smokers relative to controls $(d=-0.16$ ([95\% CI, -0.42 to 0.1$], p=0.23$ ). There were insufficient studies for meta-analysis of other measures. However, findings from the published studies indicated blunted dopamine release and lower D1 receptor availability, while findings for dopamine synthesis capacity were inconsistent.

Conclusion Our data indicate that striatal dopamine transporter availability is lower but D2/3 receptors are unaltered in smokers relative to controls. We discuss the putative mechanisms underlying this and their implications.
\end{abstract}

Keywords Tobacco smoking $\cdot$ Dopamine $\cdot$ Molecular imaging studies $\cdot$ Meta-analysis

Electronic supplementary material The online version of this article (https://doi.org/10.1007/s00213-019-05196-1) contains supplementary material, which is available to authorized users.

Oliver D. Howes

oliver.howes@kcl.ac.uk

Abhishekh H. Ashok

abhishekh.ashok@1ms.mrc.ac.uk

1 Psychiatric Imaging Group, MRC London Institute of Medical Sciences Centre (LMS), Du Cane Road, London W12 0NN, UK

2 Psychiatric Imaging Group, Faculty of Medicine, Imperial College London, Institute of Clinical Sciences (ICS), Du Cane Road, London, UK

3 Department of Psychosis Studies, Institute of Psychiatry, Psychology \& Neuroscience, King's College London, 16 De Crespigny Park, London SE5 8AB, UK

4 Department of Neuropsychiatry, Keio University School of Medicine, Tokyo, Japan

\section{Introduction}

According to the World Health Organization, estimates of 1.1 billion people smoke tobacco and 6 million deaths/year are linked to tobacco use. Moreover, second-hand smoke exposure is responsible for additional 600,000 deaths (World Drug Report 2015; https://www.unodc.org). It is estimated that tobacco-related health care costs $1.8 \%$ of GDP in many countries (Goodchild et al. 2018). Dopaminergic alterations are hypothesized to underlie addictive behavior (Ashok et al. 2017; Di Chiara and Bassareo 2007; Keiflin and Janak 2015; Nutt et al. 2015; Volkow and Morales 2015; Willuhn et al. 2014). Consistent with this, nicotine in tobacco stimulates nicotinic acetyl cholinergic (nACh) receptors leading to dopamine release (Benowitz 2009). Furthermore, preclinical studies show that the acute rewarding effects of nicotine are 
linked to two primary mechanisms. First, nicotine directly activates VTA dopaminergic neurons, which release dopamine in the nucleus accumbens (NAc). Second, it stimulates $\mathrm{nAChR}$ receptors located on the dopaminergic terminals augmenting dopamine release (Di Chiara and Imperato 1988; McGranahan et al. 2011; Zhang et al. 2009; Zhou et al. 2001). Positron emission tomography (PET) and single photon emission computed tomography (SPECT) enable dopaminergic indices to be measured in vivo in humans (Kim et al. 2013). A number of studies have investigated dopamine release, dopamine transporter, and dopamine receptor levels in smokers. However, the robustness of findings remains unclear and, to our knowledge, there has not been a previous metaanalysis of these findings. Thus, we aimed to synthesize the PET and SPECT imaging findings on dopaminergic function in smokers and to consider their implications for therapeutics. We group findings into studies of dopamine synthesis, dopamine release, dopamine transporter availability, and dopamine receptor availability. We focused on the whole striatum as it is richly innervated with dopaminergic neurons and reliably quantified with PET and SPECT in humans (Ashok et al. 2017; Egerton et al. 2010; Howes et al. 2012).

\section{Methods}

\section{Study selection}

To be included in the meta-analysis, an article needed to investigate the striatal dopaminergic system in human tobacco smokers. The MEDLINE, EMBASE, and PsycINFO databases were searched from inception date to November 18, 2018, for relevant papers without language restrictions. The electronic searches using EMBASE and PsycINFO were carried out together using Ovid. The following keywords were used: "(Positron Emission Tomography OR PET OR Single photon emission tomography OR SPET OR Single Photon Emission Computed Tomography OR SPECT) AND (dopamine OR dopamine release OR dopamine synthesis OR dopamine availability OR dopamine transporter OR dopamine reuptake OR dopamine receptor) AND (smoking OR nicotine OR nicotine dependence OR tobacco dependence)". In addition, the reference lists in the included studies and relevant review papers were screened to search for additional studies. Further details of study selection are provided in the supplementary Fig. 1.

\section{Inclusion and exclusion criteria}

The inclusion criteria were as follows: 1) original molecular imaging studies that indexed dopamine receptors, or dopamine transporters and/or dopamine release or synthesis; 2) included a group of regular (daily) tobacco smokers; and 3) reported data for the whole striatum or a striatal sub-region. We excluded studies which did not have a healthy control group or that included subjects with CNS co-morbidity. For studies with an overlap in participants, we included the study with the largest sample size without potentially missing any subject and excluded the smaller study from the meta-analysis to avoid duplication of subjects, consistent with previous molecular imaging meta-analyses (Ashok et al. 2017; Kambeitz et al. 2014).

\section{Data extraction}

The primary outcome measure was the difference in the dopaminergic imaging index between smokers and controls. The following variables were extracted from all the studies: authors, year of publication, subject characteristics of the control and smokers (group size, age, sex, substance use characteristics, comorbid substance abuse, method of abstinence confirmation, duration of abstinence, diagnosis), imaging characteristics (method, radiotracer, scanner type and resolution), route of administration of drug challenge, and modeling method.

\section{Data analysis}

The main outcome measure was the effect size calculated as Hedges' $g$ for the dopaminergic index for the whole striatum in the smokers using a random effects model. Publication bias was assessed by visual inspection of funnel plots and tested with a regression test for funnel plot asymmetry (mixed-effects meta-regression model). Trim and fill analysis was conducted to impute potentially missing studies. Heterogeneity was estimated using the $I^{2}$ value $\left(I^{2}\right.$ values $<50 \%$ indicate low to moderate heterogeneity, whereas $I^{2}>50 \%$ indicate moderate to high heterogeneity). A significance level of $p<0.05$ (twotailed) was taken as significant.

\section{Results}

The literature search yielded 610 records, from which we identified 19 relevant papers (see Supplementary Fig. 1 for the PRISMA diagram of the literature search). Fourteen of the 19 studies met criteria for inclusion in the quantitative synthesis. There was an insufficient number of studies for the meta-analysis of the D1 receptor $(n=2)$ and dopamine synthesis $(n=3)$ (Table 1$)$.

\section{Dopamine transporter}

There were seven studies assessing dopamine transporter availability in 123 smokers and 184 healthy controls 
Table 1 Molecular imaging studies on dopaminergic function in smokers

\begin{tabular}{|c|c|c|c|c|c|c|c|c|c|c|c|}
\hline $\begin{array}{l}\text { Dopamine } \\
\text { system }\end{array}$ & $\begin{array}{l}\text { Author / } \\
\text { year }\end{array}$ & $\begin{array}{l}\text { Smokers / } \\
\text { Controls, } \mathrm{n}\end{array}$ & $\begin{array}{l}\text { Male } \\
\text { smokers / } \\
\text { male } \\
\text { controls, } \mathrm{n}\end{array}$ & Diagnosis & $\begin{array}{l}\text { Years of } \\
\text { smoking, } \\
\text { mean (SD) }\end{array}$ & $\begin{array}{l}\text { Number of } \\
\text { cigarettes } \\
\text { / day }\end{array}$ & $\begin{array}{l}\text { Duration of } \\
\text { abstinence }\end{array}$ & Region of interest & $\begin{array}{l}\text { Reference } \\
\text { region }\end{array}$ & Tracer & $\begin{array}{l}\text { Results in smokers } \\
\text { compared to controls }\end{array}$ \\
\hline \multirow[t]{3}{*}{$\begin{array}{l}\text { Dopamine } \\
\text { Synthesis }\end{array}$} & $\begin{array}{l}\text { Salokangas } \\
\text { et al., 2000 } \\
\text { (Salokangas } \\
\text { et al., 2000) }\end{array}$ & $9 / 10$ & $9 / 10$ & $\begin{array}{l}\text { Nicotine } \\
\text { dependence } \\
\text { (criteria not } \\
\text { mentioned) } \\
\end{array}$ & $\begin{array}{l}\text { mean } 19.8 \\
\text { years, range } \\
15-25\end{array}$ & $\begin{array}{l}\text { mean 19.8, } \\
\text { range 16- } \\
25\end{array}$ & $\begin{array}{l}\text { current } \\
\text { smokers }\end{array}$ & $\begin{array}{l}\text { caudate and } \\
\text { putamen }\end{array}$ & $\begin{array}{l}\text { occipital cx } \\
\text { (Hietala et al., } \\
\text { 1999) }\end{array}$ & 18F-DOPA & $\begin{array}{l}\text { putamen and } \\
\text { caudate }\end{array}$ \\
\hline & $\begin{array}{l}\text { Bloomfield } \\
\text { et al., 2014 } \\
\text { (Bloomfield } \\
\text { et al., 2014) }\end{array}$ & $15 / 15$ & $10 / 10$ & $\begin{array}{l}12 / 15 \\
\text { smokers met } \\
\text { DSM-IV } \\
\text { criteria for } \\
\text { nicotine } \\
\text { dependence }\end{array}$ & $\begin{array}{l}\text { not } \\
\text { mentioned }\end{array}$ & $8.1(4.1)$ & $\begin{array}{l}\text { current } \\
\text { smokers }\end{array}$ & striatum & cerebellum & 18F-DOPA & $\Leftrightarrow$ \\
\hline & $\begin{array}{l}\text { Redemacher } \\
\text { et al., } 2016 \\
\text { (Rademache } \\
\text { r et al., } \\
\text { 2016) } \\
\end{array}$ & $30 / 15$ & $30 / 15$ & $\begin{array}{l}\text { DSM-IV } \\
\text { nicotine } \\
\text { dependence }\end{array}$ & $\begin{array}{l}\text { mean } 11.7 \\
\text { years }\end{array}$ & $17.7(6.0)$ & $\begin{array}{l}\text { current } \\
\text { smokers or } \\
\text { in acute } \\
\text { abstinence } \\
\text { (6 hours) } \\
\end{array}$ & $\begin{array}{l}\text { right and left Nac, } \\
\text { ventral and dorsal } \\
\text { caudate, ventral } \\
\text { and dorsal } \\
\text { putamen }\end{array}$ & cerebellum & 18F-DOPA & \\
\hline \multirow[t]{7}{*}{$\begin{array}{l}\text { Dopamine } \\
\text { Transporter }\end{array}$} & $\begin{array}{l}\text { Staley et al., } \\
2001 \text { (Staley } \\
\text { et al., 2001) }\end{array}$ & $21 / 21$ & $9 / 9$ & $\begin{array}{l}\text { SCID, FTND } \\
\text { and plasma } \\
\text { cotinine }\end{array}$ & $24.5(10.0)$ & $23.6(4.3)$ & \begin{tabular}{|l|} 
current \\
smokers
\end{tabular} & striatum & cerebellum & $\begin{array}{l}\text { 123I-beta- } \\
\text { CIT }\end{array}$ & $\Leftrightarrow$ \\
\hline & $\begin{array}{l}\text { Newberg et } \\
\text { al., 2007 } \\
\text { (Newberg et } \\
\text { al., 2007) }\end{array}$ & $8 / 46$ & $4 / 21$ & $\begin{array}{l}\text { Structured } \\
\text { interview } \\
\text { regarding } \\
\text { smoking } \\
\text { habits } \\
\end{array}$ & $\begin{array}{l}\text { not } \\
\text { mentioned }\end{array}$ & $15(10)$ & $\begin{array}{l}\text { current } \\
\text { smokers }\end{array}$ & $\begin{array}{l}\text { right and left } \\
\text { caudate, anterior } \\
\text { putamen, } \\
\text { posterior } \\
\text { putamen } \\
\end{array}$ & $\begin{array}{l}\text { supratentorial } \\
\text { structures not } \\
\text { specified }\end{array}$ & $\begin{array}{l}\text { Tc-99m } \\
\text { TRODAT-1 }\end{array}$ & $\begin{array}{l}\text { bilateral caudate, } \\
\text { right anterior } \\
\text { putamen, left } \\
\text { posterior putamen }\end{array}$ \\
\hline & $\begin{array}{l}\text { Yang et al., } \\
2008 \text { (Yang } \\
\text { et al., 2008) }\end{array}$ & $11 / 11$ & $11 / 11$ & $\begin{array}{l}\text { FTND (no } \\
\text { cut-off } \\
\text { defined), } \\
\text { smoking } \\
\text { history } \\
\text { questionnair } \\
\text { e }\end{array}$ & $\begin{array}{l}\text { not } \\
\text { mentioned }\end{array}$ & $\begin{array}{l}\text { not } \\
\text { mentioned }\end{array}$ & $\begin{array}{l}\text { current } \\
\text { smokers }\end{array}$ & striatum & occipital cx & $\begin{array}{l}\text { Tc-99m } \\
\text { TRODAT-1 }\end{array}$ & \\
\hline & $\begin{array}{l}\text { Cosgrove et } \\
\text { al., 2009 } \\
\text { (Cosgrove et } \\
\text { al., 2009b) }\end{array}$ & $6 / 8$ & $4 / 4$ & $\begin{array}{l}\text { Plasma } \\
\text { cotinine } \\
\text { level } \\
>150 \mathrm{ng} / \mathrm{ml} \\
\text { on day of } \\
\text { intake } \\
\end{array}$ & $22.2(9.7)$ & $24.2(4.9)$ & $\begin{array}{l}\text { current } \\
\text { smokers }\end{array}$ & striatum & cerebellum & $\begin{array}{l}\text { 123I-beta- } \\
\text { CIT }\end{array}$ & $\Longleftrightarrow$ \\
\hline & $\begin{array}{l}\text { Leroy et al., } \\
2012 \text { (Leroy } \\
\text { et al., 2012) }\end{array}$ & $14 / 11$ & $14 / 11$ & $\begin{array}{l}\text { DSM-IV } \\
\text { nicotine } \\
\text { dependence }\end{array}$ & $12.1(8.5)$ & $17.6(5.3)$ & \begin{tabular}{|l|} 
current \\
smokers
\end{tabular} & $\begin{array}{l}\text { right and left } \\
\text { dorsal caudate } \\
\text { and dorsal } \\
\text { putamen }\end{array}$ & cerebellum & 11C-PE2I & \\
\hline & $\begin{array}{l}\text { Lin et al., } \\
2012 \text { (Lin et } \\
\text { al., 2012) }\end{array}$ & $37 / 23$ & $22 / 8$ & $\begin{array}{l}\text { Self- } \\
\text { reported } \\
\text { smoking } \\
\text { habits }\end{array}$ & $\begin{array}{l}\text { not } \\
\text { mentioned }\end{array}$ & $\begin{array}{l}<1 \text { pack } \\
\text { per day } \\
(n=20), 1 \\
\text { pack } \leq \text { per } \\
\text { day }(n=17)\end{array}$ & $10-12$ hours & striatum & occipital cx & $\begin{array}{l}\text { Tc-99m } \\
\text { TRODAT-1 }\end{array}$ & \\
\hline & $\begin{array}{l}\text { Thomsen et } \\
\text { al., } 2013 \\
\text { (Thomsen et } \\
\text { al., 2013) }\end{array}$ & $26 / 64$ & $15 / 34$ & $\begin{array}{l}\text { Interview, } \\
\text { Copenhagen } \\
\text { Smoking } \\
\text { Questionnair } \\
\text { e (no cut-off } \\
\text { given) }\end{array}$ & $\begin{array}{l}\text { not } \\
\text { mentioned }\end{array}$ & $11.2(8.6)$ & $\begin{array}{l}\text { current } \\
\text { smokers }\end{array}$ & striatum & $\begin{array}{l}\text { cerebellum } \\
\text { (Jensen et al., } \\
\text { 2011) }\end{array}$ & $\begin{array}{l}\text { 123I-FP- } \\
\text { CIT }\end{array}$ & $\begin{array}{l}\Longleftrightarrow \text { active } \\
\text { smokers, ex- } \\
\text { smokers and non- } \\
\text { smokers }\end{array}$ \\
\hline \multirow[t]{2}{*}{$\begin{array}{l}\text { Dopamine } \\
\text { release }\end{array}$} & $\begin{array}{l}\text { Busto et al., } \\
2009 \text { (Busto } \\
\text { et al., 2009) }\end{array}$ & $9 / 11$ & $8 / 3$ & FTND $\geq 3$ & $\begin{array}{l}\text { mean } 16.7 \\
\text { years }\end{array}$ & $15.2(3.3)$ & $\begin{array}{l}\text { current } \\
\text { smokers }\end{array}$ & striatum & cerebellum & $\begin{array}{l}\text { 11C- } \\
\text { raclopride- } \\
\text { oral d- } \\
\text { amphetam } \\
\text { ine } \\
\text { challenge } \\
\end{array}$ & $\begin{array}{l}\text { (oral d- } \\
\text { amphetamine } \\
\text { challenge) }\end{array}$ \\
\hline & $\begin{array}{l}\text { Wiers et al., } \\
2017 \text { (Wiers } \\
\text { et al., 2017) }\end{array}$ & $\begin{array}{l}8 \text { current } \\
\text { smokers, } \\
10 \text { ex- } \\
\text { smokers/ } \\
18\end{array}$ & $6,7 / 12$ & $\begin{array}{l}\text { Smoking } \\
\text { history }\end{array}$ & $\begin{array}{l}\text { mean } 11.0 \\
\text { years in } \\
\text { current } \\
\text { smokers, } \\
11.2 \text { years in } \\
\text { ex-smokers }\end{array}$ & $\begin{array}{l}\text { mean } 7.43 \\
\text { in current } \\
\text { smokers, } \\
8.69 \text { in ex- } \\
\text { smokers }\end{array}$ & $\begin{array}{l}\text { In ex- } \\
\text { smokers } \\
\text { mean } \\
\text { abstinence- } \\
3.53 \text { years }\end{array}$ & $\begin{array}{l}\text { Caudate, } \\
\text { putamen and } \\
\text { ventral striatum }\end{array}$ & cerebellum & $\begin{array}{l}\text { 11C- } \\
\text { raclopride- } \\
\text { Methylphe } \\
\text { nidate } \\
\text { challenge }\end{array}$ & $\begin{array}{l}\quad \begin{array}{l}\text { in current } \\
\text { smokers and } \\
\text { increased in ex- }\end{array} \\
\text { smokers, however it } \\
\text { was not statistically } \\
\text { significant }\end{array}$ \\
\hline
\end{tabular}




\begin{tabular}{|c|c|c|c|c|c|c|c|c|c|c|c|}
\hline \multirow[t]{8}{*}{$\begin{array}{l}\text { Dopamine } \\
\text { receptor }\end{array}$} & $\begin{array}{l}\text { Yang et al., } \\
2006 \text { (Yang } \\
\text { et al., 2006) }\end{array}$ & $15 / 15$ & $15 / 15$ & $\begin{array}{l}\text { FTND }>5 \text {, } \\
\text { smoking for } \\
\text { longer than } \\
5 \text { years }\end{array}$ & $\begin{array}{l}9.2(8.7) \\
\text { years }\end{array}$ & $\begin{array}{l}18.75 \\
(6.78)\end{array}$ & $\begin{array}{l}\text { current } \\
\text { smokers }\end{array}$ & striatum & cerebellum & 123-IBZM & $\Leftrightarrow$ \\
\hline & $\begin{array}{l}\text { Takahashi et } \\
\text { al., } 2008 \\
\text { (Takahashi } \\
\text { et al., 2008) }\end{array}$ & $6 / 6$ & $6 / 6$ & $\begin{array}{l}\text { Smoking } \\
\text { history }>4 \\
\text { years, at } \\
\text { least } 15 \\
\text { cigarettes/d } \\
\text { ay, FTND (no } \\
\text { cut-off } \\
\text { defined) }\end{array}$ & $\begin{array}{l}\text { At least } 4 \\
\text { years }\end{array}$ & $\geq 15$ & 24 hours & $\begin{array}{l}\text { right and left } \\
\text { dorsal caudate, } \\
\text { dorsal putamen, } \\
\text { ventral caudate, } \\
\text { ventral putamen }\end{array}$ & cerebellum & $\begin{array}{l}\text { 11C- } \\
\text { raclopride }\end{array}$ & $\Leftrightarrow$ \\
\hline & $\begin{array}{l}\text { Yang et al., } \\
2008 \text { (Yang } \\
\text { et al., 2008) }\end{array}$ & $11 / 11$ & $11 / 11$ & $\begin{array}{l}\text { FTND (no } \\
\text { cut-off } \\
\text { defined), } \\
\text { smoking } \\
\text { history } \\
\text { questionnair } \\
\text { e }\end{array}$ & $\begin{array}{l}\text { not } \\
\text { mentioned }\end{array}$ & $\begin{array}{l}\text { not } \\
\text { mentioned }\end{array}$ & $\begin{array}{l}\text { current } \\
\text { smokers }\end{array}$ & striatum & occipital cx & 123-IBZM & $\Leftrightarrow$ \\
\hline & $\begin{array}{l}\text { Busto et al., } \\
2009 \text { (Busto } \\
\text { et al., 2009) }\end{array}$ & $9 / 11$ & $8 / 3$ & FTND $\geq 3$ & $\begin{array}{l}\text { Mean } 16.7 \\
\text { years }\end{array}$ & $15.2(3.3)$ & $\begin{array}{l}\text { current } \\
\text { smokers }\end{array}$ & striatum & cerebellum & $\begin{array}{l}\text { 11C- } \\
\text { raclopride }\end{array}$ & V \\
\hline & $\begin{array}{l}\text { Brown et al., } \\
2012 \text { (Brown } \\
\text { et al., 2012) }\end{array}$ & $19 / 18$ & $10 / 9$ & $\begin{array}{l}\text { nicotine } \\
\text { dependence }\end{array}$ & $\begin{array}{l}240(135), \\
250(120) \\
\text { pack years } \\
\text { (description } \\
\text { error?) }\end{array}$ & $13(6.9)$ & $\begin{array}{l}\text { current } \\
\text { smokers }\end{array}$ & $\begin{array}{l}\text { caudate and } \\
\text { putamen }\end{array}$ & cerebellum & $\begin{array}{l}\text { 18F- } \\
\text { Fallypride }\end{array}$ & $\begin{array}{l}\text { in male smokers } \\
\text { than female } \\
\text { smokers, and } \\
\text { male non-smokers }\end{array}$ \\
\hline & $\begin{array}{l}\text { Albrecht et } \\
\text { al., } 2013 \\
\text { (Albrecht et } \\
\text { al., 2013) }\end{array}$ & $21 / 26$ & $18 / 16$ & $\begin{array}{l}\text { FTND (no } \\
\text { cut-off } \\
\text { defined) }\end{array}$ & $\begin{array}{l}\text { Not } \\
\text { mentioned }\end{array}$ & $\begin{array}{l}\text { Not } \\
\text { mentioned }\end{array}$ & $\begin{array}{l}\text { Not } \\
\text { mentioned } \\
\text { (majority on } \\
\text { nicotine } \\
\text { patch) }\end{array}$ & $\begin{array}{l}\text { left and right, pre- } \\
\text { and post- dorsal } \\
\text { caudate, dorsal } \\
\text { putamen, and } \\
\text { ventral striatum }\end{array}$ & cerebellum & $\begin{array}{l}\text { 11C- } \\
\text { raclopride }\end{array}$ & 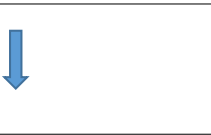 \\
\hline & $\begin{array}{l}\text { Okita et al., } \\
2016 \text { (Okita } \\
\text { et al., 2016) }\end{array}$ & $18 / 19$ & $11 / 10$ & $\begin{array}{l}13 \text { smokers } \\
\text { met DSM-IV } \\
\text { criteria for } \\
\text { nicotine } \\
\text { dependence }\end{array}$ & $\begin{array}{l}13.8(10.1) \\
\text { pack-years }\end{array}$ & $13.3(4.1)$ & $\begin{array}{l}\text { Current } \\
\text { smokers }\end{array}$ & $\begin{array}{l}\text { caudate, } \\
\text { putamen, } \\
\text { midbrain, insula }\end{array}$ & cerebellum & $\begin{array}{l}\text { 18F- } \\
\text { Fallypride }\end{array}$ & $\begin{array}{l}\Longleftrightarrow \text { in striatum } \\
\text { Greater midbrain } \\
\text { BPND in the female, } \\
\text { but not male smokers } \\
\text { than corresponding } \\
\text { non-smokers }\end{array}$ \\
\hline & $\begin{array}{l}\text { Wiers et al } \\
\text { (Wiers et al., } \\
\text { 2017) }\end{array}$ & $\begin{array}{l}8 \text { current } \\
\text { smokers, } \\
10 \text { ex- } \\
\text { smokers/ } \\
18\end{array}$ & $6,7 / 12$ & $\begin{array}{l}\text { Smoking } \\
\text { history }\end{array}$ & $\begin{array}{l}\text { mean } 11.0 \\
\text { years in } \\
\text { current } \\
\text { smokers, } \\
11.2 \text { years in } \\
\text { ex-smokers }\end{array}$ & $\begin{array}{l}\text { mean } 7.43 \\
\text { in current } \\
\text { smokers, } \\
8.69 \text { in ex- } \\
\text { smokers }\end{array}$ & $\begin{array}{l}\text { In ex- } \\
\text { smokers } \\
\text { mean } \\
\text { abstinence- } \\
3.53 \text { years }\end{array}$ & $\begin{array}{l}\text { Caudate, } \\
\text { putamen and } \\
\text { ventral striatum }\end{array}$ & cerebellum & $\begin{array}{l}\text { 11C- } \\
\text { raclopride }\end{array}$ & $\begin{array}{l}\begin{array}{l}\text { in current } \\
\text { smokers } \\
\text { compared to } \\
\text { controls }\end{array} \\
\text { No difference between } \\
\text { ex-smokers and } \\
\text { controls }\end{array}$ \\
\hline \multirow[t]{2}{*}{ D1 receptor } & $\begin{array}{l}\text { Dagher et } \\
\text { al., } 2001 \\
\text { (Dagher et } \\
\text { al., 2001) }\end{array}$ & $11 / 18$ & $6 / 9$ & $\begin{array}{l}\text { not } \\
\text { mentioned }\end{array}$ & $\begin{array}{l}\text { not } \\
\text { mentioned }\end{array}$ & $19.4(6)$ & $\begin{array}{l}\text { abuse of } \\
\text { other drugs } \\
\text { screened in } \\
\text { interview }\end{array}$ & $\begin{array}{l}\text { caudate, } \\
\text { putament, NAC }\end{array}$ & cerebellum & $\begin{array}{l}\text { 11C- } \\
\text { SCH23390 }\end{array}$ & 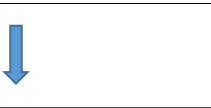 \\
\hline & $\begin{array}{l}\text { Yasuno et } \\
\text { al., } 2007 \\
\text { (Yasuno et } \\
\text { al., 2007) }\end{array}$ & $18 / 12$ & $17 / 12$ & $\begin{array}{l}\text { DSM-IV } \\
\text { nicotine } \\
\text { dependence }\end{array}$ & $\begin{array}{l}\text { not } \\
\text { mentioned }\end{array}$ & mean 23.5 & $\begin{array}{l}\text { screened in } \\
\text { interview }\end{array}$ & ventral striatum & cerebellum & $\begin{array}{l}11 \mathrm{C}- \\
\text { SCH23390 }\end{array}$ & $\Pi$ \\
\hline
\end{tabular}


(Cosgrove et al. 2009b; Leroy et al. 2012; Lin et al. 2012; Newberg et al. 2007; Staley et al. 2001; Thomsen et al. 2013; Yang et al. 2008). The meta-analysis showed a significant reduction in dopamine transporter availability in the smoker relative to control groups with an effect size of -0.72 ([95\% CI, -1.38 to -0.05$], p=0.03$ ) (Figure 1).

\section{Heterogeneity and sensitivity analyses}

The $I^{2}$ value was $84 \%$ (95\% CI, 60-97\%), indicating high heterogeneity between studies. The regression test for funnel plot asymmetry was not significant $(t=-0.5, \mathrm{df}=5, p=0.64)$. However, visual inspection of the funnel plot revealed asymmetry, indicating possible publication bias. The trim-and-fill analysis indicates two missing studies on the left side of the funnel plot (Supplementary Figure 2). However, the results remained significant after correcting for putatively missing studies (adjusted effect size $=-1.0,(95 \% \mathrm{CI},-1.6$ to -0.37$)$, $p<0.01)$.

\section{Dopamine receptor availability}

There were eight studies assessing dopamine receptor availability in 107 smokers and 124 healthy controls (Albrecht et al. 2013; Brown et al. 2012; Busto et al. 2009; Okita et al. 2016; Takahashi et al. 2008; Wiers et al. 2017; Yang et al. 2006,2008 ). The meta-analysis revealed no significant difference in D2/3 receptor availability in smokers relative to controls with an effect size of -0.16 ([95\% CI, -0.42 to 0.1$], p=$ 0.23) (Figure 2).

\section{Heterogeneity and sensitivity analyses}

The $I^{2}$ value was $0 \%$ (95\% CI, 0-79\%), indicating heterogeneity was low. The regression test for funnel plot asymmetry was not significant $(t=-1.1, \mathrm{df}=6, p=0.32$ ). However, a visual inspection of the funnel plot revealed asymmetry, indicating possible publication bias. The trim-and-fill analysis indicated that there were potentially one missing studies on the left side of the funnel plot (Supplementary Fig. 3). Nevertheless, the summary effect size remained nonsignificant after correcting for these putatively missing studies (corrected effect size: -0.2 [95\% CI, -0.45 to 0.05$] ; z=-1.5$; $p=0.12$ ).

\section{Dopamine D1 receptor availability}

Two studies reported D1 receptor availability, which used [11C] SCH23390 to compare smokers with controls (Dagher et al. 2001; Yasuno et al. 2007). Both studies reported significant reductions in D1 receptor availability in smokers compared to controls.

\section{Dopamine synthesis}

Meta-analysis was not conducted as there were only three studies. There is a substantial discrepancy in the dopamine synthesis capacity in smokers. Salokangas et al. 2000 demonstrated higher dopamine synthesis in heavy smokers relative to controls (Salokangas et al. 2000), Bloomfield et al. 2014 showed no change in moderate smokers (Bloomfield et al. 2014b), while Rademacher et al. 2016 demonstrated lower dopamine synthesis relative to controls in a sample of heavy smokers who met criteria for dependence (Rademacher et al. 2016). Interestingly, reduced dopamine synthesis in heavy smokers normalized after 3 months of abstinence (Rademacher et al. 2016). Overall, the effect of smoking on dopamine synthesis is unclear and further studies in both moderate and heavy smokers are needed.

\section{Dopamine release}

Seminal work in the 1990s developed paradigms to assess dopamine release in vivo using molecular imaging (Breier et al. 1999; Laruelle et al. 1995). This and subsequent work has determined that the reduction in striatal binding of radiotracers such as $[11 \mathrm{C}]$-raclopride following the administration of amphetamine or methylphenidate is closely related to the
Fig. 1 Studies of dopamine transporter availability in tobacco smokers relative to controls. The forest plot shows the effects sizes estimated using a random effects model and $95 \%$ confidence intervals of the difference between smokers and controls. There was an overall significant decrease in the dopamine transporter availability in smokers relative to controls with a moderate to large effect size (0.72 [95\% CI, -1.38 to -0.05$]$, $p<0.05)$

\begin{tabular}{|c|c|c|}
\hline $\begin{array}{l}\text { Staley et al., } 2001 \\
\text { Newberg et al., } 2007 \\
\text { Yang et al., } 2008 \\
\text { Cosgrove et al., } 2009 \\
\text { Leroy et al., } 2012 \\
\text { Lin et al., } 2012 \\
\text { Thomsen et al., } 2013\end{array}$ & $\longmapsto$ & 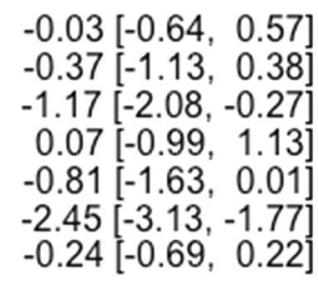 \\
\hline RE Model & 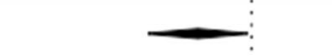 & $-0.72[-1.38,-0.05]$ \\
\hline Г & $T$ & ᄀ \\
\hline-4 & $\begin{array}{lll}-3 & -2 & -1\end{array}$ & 2 \\
\hline
\end{tabular}


Fig. 2 Studies of dopamine D2/3 receptor availability in tobacco smokers relative to controls. The forest plot shows the effect sizes estimated using a random effects model and $95 \%$ confidence intervals of $\mathrm{D} 2 / 3$ receptor binding potentials. There was no significant difference in dopamine receptor availability in smokers compared to controls $(-0.16$ [ $95 \% \mathrm{CI},-0.42$ to -0.1$]$, $p>0.05)$

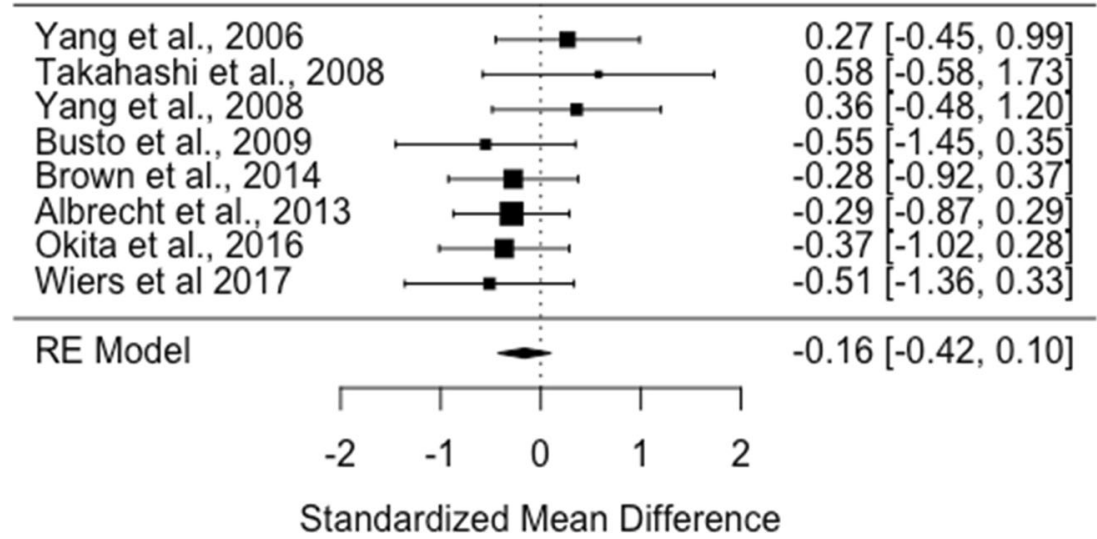

magnitude of dopamine release (Abi-Dargham et al. 2009; Egerton et al. 2009). Only two studies investigated the dopamine release following amphetamine or methylphenidate. One study showed smokers had lower dopamine release compared to healthy control (Busto et al. 2009), while the other study reported a trend level reduction in dopamine release in smokers (Wiers et al. 2017). Thirteen studies measured dopamine release following nicotine administration during or prior to the scan (Barrett et al. 2004; Brody et al. 2010, 2009b, 2006b, 2004; Cosgrove et al. 2014; Domino et al. 2013; Le Foil et al. 2014; Montgomery et al. 2007; Scott et al. 2007a; Takahashi et al. 2008; Weinstein et al. 2016; Wing et al. 2015). The majority of these studies did not have control arm and there was substantial variation in the study design with respect to route of administration, scanning, and nicotine administration duration. Thus, these studies did not meet our inclusion criteria for meta-analysis. Two studies (Barrett et al. 2004; Montgomery et al. 2007) did not report change in binding potential while other studies reported $7-27 \%$ reduction in the binding potential (Brody et al. 2006b, 2004; Le Foil et al. 2014; Scott et al. 2007b; Takahashi et al. 2008).

\section{Discussion}

Our main findings are that dopamine transporter availability is reduced with a medium to large effect size and that D2/3 receptor availability in unaltered in smokers compared to healthy controls (Hedges' g: -0.72 and -0.16 respectively). Our sensitivity analyses of the dopamine D2/3 receptor availability showed consistent results, and we noted low heterogeneity. However, there was significant heterogeneity in the dopamine transporter finding.

There were insufficient studies to meta-analyze findings on dopamine synthesis in smokers, and the results of studies were inconsistent, indicating further, large studies are needed to determine if dopamine synthesis capacity is altered by smoking. Similarly, there were too few studies for metaanalyses of dopamine release or D1 receptor levels, although findings indicated blunted dopamine release and lower D1 levels in smokers. However, there were only two studies for each of these dopamine measures, and the studies had small sample sizes. Thus, while results indicate blunted dopamine release and D1 levels in smokers, further studies are needed before the consistency and robustness of these alterations can be determined.

Our finding that D2/3 receptor levels are unaltered is consistent with post-mortem evidence, which also shows unaltered D2 receptor levels in smokers (Court et al. 1998). However, our finding of reduced dopamine transporter availability is not consistent with a human post-mortem study which found DAT levels to be unaltered in smokers (Court et al. 1998). This discrepancy between our in vivo findings and the human post-mortem study could reflect changes in post-mortem or differences in the techniques. This study used a $[3 \mathrm{H}]$ mazindol binding assay, and evidence indicates mazindol binds to serotonin, norepinephrine, and dopamine transporters (Kung et al. 1995; Owens et al. 1997). Thus, binding to serotonin and norepinephrine transporters could have confounded the post-mortem findings, although it should be appreciated that this is also a potential issue for some PET radiotracers. In contrast, there is some preclinical evidence that DAT function is reduced after nicotine administration as measured by dopamine reuptake in the nucleus (Danielson et al. 2014), and that stimulation of acetylcholine receptor suppresses DAT activity (Huang et al. 1999), consistent with our findings.

\section{Strengths and limitations}

Similar to other meta-analyses of psychiatric imaging studies, there are variations between studies in terms of co-morbid use of other substances such as alcohol and variation in methods, in the radiotracer used, scanners and different definition of the striatum (Ashok et al. 2017; Howes et al. 2012) (Table 1 and Supplementary Table 1). The studies included in the metaanalysis used tracers such as TRODAT and beta-CIT to quantify DAT, but a potential issue is that these tracers also have 
affinity for serotonin transporters (de Win et al. 2005; Dresel et al. 1999; Stengler-Wenzke et al. 2006). This, coupled with the experimental variables discussed above, could contribute to the relatively high inconsistency we found in the dopamine transporter findings. Nevertheless, the random effects model we used allows for variations in effects.

An association has been reported between a variable number tandem repeats (VNTR) polymorphism of DAT gene (SLC6A3) and DAT availability (Heinz et al. 2000) and this was replicated in an in vitro study (VanNess et al. 2005), although subsequent studies have been inconsistent (Faraone et al. 2014). Variation in other genes related to dopamine function has also been associated with differences dopamine imaging measures (Brody et al. 2006b; Dahoun et al. 2018). As the majority of the studies included in our meta-analysis have not reported genotype data, a potential confounding effect of genetic differences between groups influencing the results cannot be ruled out. Of course, the effects of these genetic variants on the dopamine system may be a mechanistic link that explains why some people are vulnerable to become tobacco smokers. In view of this, it would be useful for future studies to genotype participants for gene variants known to impact on the dopamine system where possible.

A few studies did not explicitly exclude comorbid substance use or report current and past substance use in subjects (see Supplementary Table 1 for details). A meta-analysis has shown that stimulant users have lower dopamine receptor, transporter, and release (Ashok et al. 2017) and alcohol, cannabis, and opiate use may also alter the dopaminergic system (Ashok et al. 2017; Bloomfield et al. 2016; Bloomfield et al. 2014a; Nutt et al. 2015). As such, it is possible that the inclusion of subjects with comorbid stimulant or other substance use could be a confound in some studies. However, the majority of the studies explicitly excluded subjects with current comorbid substance use, suggesting that comorbid substance use is unlikely to have had a major effect on our findings. Nevertheless, it would be useful for all future studies to either exclude comorbid substance use or report it to enable this possibility to be investigated further.

As shown in Table 1, there is substantial variation between studies in the duration of abstinence before the scan. Microdialysis studies have shown that dopamine release reaches peak between 20 and 40 min after nicotine administration and returns to baseline after $60 \mathrm{~min}$ (Marshall et al. 1997; Mifsud et al. 1989). As acute smoking-induced dopamine release can displace binding of radiotracers such as [11C] raclopride (Brody et al. 2006b), recent smoking could be a potential confound. In addition, in a study which compared D2 receptor availability and release in a group of current and ex-smokers, prolonged abstinence was shown to normalize the dopaminergic alteration (Wiers et al. 2017). Future longitudinal studies would be useful to determine the temporal course of dopaminergic alterations and abstinence from smoking. A general limitation of the literature is that there are few studies with large sample sizes in dopamine synthesis, release, and D1 receptor availability. Thus we could not metaanalyze these findings.

\section{Implications for the understanding of the neurobiology of tobacco smoking}

Preclinical studies using in vivo micro-dialysis have shown that the acute administration of nicotine increases extracellular dopamine concentrations in the striatum, specifically in nucleus accumbens (Damsma et al. 1988; Gaddnas et al. 2001; McCallum et al. 2012; Watkins et al. 2000). Knockout animal models have shown that nicotinic acetylcholine receptor stimulation is required for this effect (Marubio et al. 2003; Picciotto et al. 1999). Human in vivo imaging studies also show that acute exposure to nicotine leads to increased synaptic dopamine, despite substantial variation in study methodology (Barrett et al. 2004; Brody et al. 2010, 2009b, 2004; Cosgrove et al. 2015; Domino et al. 2012, 2013; Le Foll et al. 2014; Montgomery et al. 2007; Scott et al. 2007b). Moreover, molecular imaging studies have shown that occupancy of the nicotinic acetylcholine receptor is associated with the subjective hedonic response of smoking (Brody et al. 2009a, 2011, 2006a, 2014, 2013; Cosgrove et al. 2009a; Cosgrove et al. 2012; Dubroff et al. 2015; Lotfipour et al. 2012; Staley et al. 2006). Thus, there is converging evidence from pre-clinical and human studies that nicotinic acetylcholine receptorinduced dopamine release occurs acutely with tobacco smoking.

In contrast, preclinical studies have shown that chronic (34 weeks) nicotine exposure reduces basal dopamine level (Zhang et al. 2012). Electrophysiological studies are consistent with these findings and report that that chronic nicotine administration reduces the firing rate of A10 dopamine neurons (Rasmussen and Czachura 1995). However, D2 receptor availability remains unaltered in chronically nicotine-treated rats (Kirch et al. 1992). Our findings in humans on D2 receptor availability in smokers are consistent with these findings.

Two basic models are possible to account for our findings of reduced dopamine transporter and unaltered D2 receptor availability. The first is that reduced transporter levels may be compensatory in response to reduced tonic dopamine levels or other dopaminergic changes in the synapse. However, normal D2/3 receptor levels are less easy to understand in the context of presynaptic reductions, as it would be expected that they would increase in response to reduced tonic dopamine levels, albeit longitudinal studies are needed to test whether there is a change in D2/3 receptor levels with chronic smoking in humans.

The second model is that lower dopamine transporter levels may underlie the pathoetiology of smoking, and precede its onset. Thus, individuals at risk of smoking may have lower 
dopamine transporter levels secondary to genetic and environmental risk factors. Lower transporter levels may then mean that the acute effects of smoking, including dopamine release, are larger, potentially making these individuals more vulnerable to become regular users. Future longitudinal human PET studies are needed to investigate changes in the dopamine transporter levels, and other aspects of the dopamine system, prior to and during nicotine addiction, and following cessation to test these models. This will also potentially identify biomarkers to guide treatment and predict outcomes.

\section{Conclusions}

There is evidence for lower dopamine transporter availability with a moderate to large effect size but normal D2 dopamine receptor availability in smokers. These findings identify dopamine transporter abnormalities as either involved in the pathophysiology of tobacco dependence or as a biological response to long-term exposure to tobacco. Further studies are needed to determine the nature of alterations in other aspects of the dopamine system, and whether there are longitudinal changes in dopamine transporter levels during the acquisition of a smoking habit.

Funding/support This study was funded by grants MC-A656-5QD30 from the Medical Research Council-UK, 666 from the Maudsley Charity 094849/Z/10/Z from the Brain and Behavior Research Foundation, and Wellcome Trust to Dr. Howes and King's College London scholarship to Dr. Ashok

Role of the funder/sponsor The funders had no role in the design and conduct of the study; collection, management, analysis, and interpretation of the data; preparation, review, or approval of the manuscript; and decision to submit the manuscript for publication.

Author contributions Dr. Ashok and Dr. Mizuno had full access to all the data in the study and took responsibility for the integrity of the data and the accuracy of the data analysis.

Study concept and design: Ashok and Howes

Acquisition, analysis, or interpretation of data: All authors

Drafting of the manuscript: All authors

Critical revision of the manuscript for important intellectual content: All authors

Statistical analysis: Ashok

Administrative, technical, or material support: Ashok and Mizuno

Study supervision: Howes

\section{Compliance with ethical standards}

Conflict of interest disclosure Dr. Ashok conducts research funded by the Medical Research Council (UK) and King's College London. Dr. Mizuno has received manuscript fees or speaker's honoraria from Sumitomo Dainippon Pharma and Yoshitomi Yakuhin, fellowship grants from Japan Society for the Promotion of Science, Astellas Foundation for Research on Metabolic Disorders, Japanese Society of Clinical Neuropsychopharmacology, and Mochida Memorial Foundation for Medical and Pharmaceutical Research, and consultant fees from Bracket within the past 3 years. Prof. Howes conducts research funded by the Medical Research Council (UK), the National Institute of Health Research (UK), and the Maudsley Charity. Prof Howes has received investigator-initiated research funding from and/or participated in advisory/speaker meetings organized by Astra-Zeneca, BMS, Eli Lilly, Jansenn, Lundbeck, Lyden-Delta, Servier, and Roche. Neither Prof. Howes nor his family have been employed by or have holdings/of a financial stake in any biomedical company.

Open Access This article is distributed under the terms of the Creative Commons Attribution 4.0 International License (http:// creativecommons.org/licenses/by/4.0/), which permits unrestricted use, distribution, and reproduction in any medium, provided you give appropriate credit to the original author(s) and the source, provide a link to the Creative Commons license, and indicate if changes were made.

\section{References}

Abi-Dargham A, van de Giessen E, Slifstein M, Kegeles LS, Laruelle M (2009) Baseline and amphetamine-stimulated dopamine activity are related in drug-naive schizophrenic subjects. Biol Psychiatry 65: 1091-1093

Albrecht DS, Kareken DA, Yoder KK (2013) Effects of smoking on D2/ D3 striatal receptor availability in alcoholics and social drinkers. Brain Imaging Behav 7:326-334

Ashok AH, Mizuno Y, Volkow ND, Howes OD (2017) Association of stimulant use with dopaminergic alterations in users of cocaine, amphetamine, or methamphetamine: a systematic review and meta-analysis. JAMA Psychiatry 74:511-519

Barrett SP, Boileau I, Okker J, Pihl RO, Dagher A (2004) The hedonic response to cigarette smoking is proportional to dopamine release in the human striatum as measured by positron emission tomography and [11C]raclopride. Synapse 54:65-71

Benowitz NL (2009) Pharmacology of nicotine: addiction, smokinginduced disease, and therapeutics. Annu Rev Pharmacol Toxicol 49:57-71

Bloomfield MA, Morgan CJ, Egerton A, Kapur S, Curran HV, Howes OD (2014a) Dopaminergic function in cannabis users and its relationship to cannabis-induced psychotic symptoms. Biol Psychiatry 75:470-478

Bloomfield MAP, Pepper F, Egerton A, Demjaha A, Tomasi G, Mouchlianitis E, Maximen L, Veronese M, Turkheimer F, Selvaraj S, Howes OD (2014b) Dopamine function in cigarette smokers: an [18]-DOPA PET study. Neuropsychopharmacology 39:2397-2404

Bloomfield MA, Ashok AH, Volkow ND, Howes OD (2016) The effects of delta(9)-tetrahydrocannabinol on the dopamine system. Nature 539:369-377

Breier A, Su TP, Malhotra AK, Elman I, Adler CM, Weisenfeld NI, Pickar D (1999) Effects of atypical antipsychotic drug treatment on amphetamine-induced striatal dopamine release in patients with psychotic disorders. Neuropsychopharmacology 20:340-345

Brody AL, Olmstead RE, London ED, Farahi J, Meyer JH, Grossman P, Lee GS, Huang J, Hahn EL, Mandelkern MA (2004) Smokinginduced ventral striatum dopamine release. Am J Psychiatry 161: $1211-1218$

Brody AL, Mandelkern MA, London ED, Olmstead RE, Farahi J, Scheibal D, Jou J, Allen V, Tiongson E, Chefer SI, Koren AO, Mukhin AG (2006a) Cigarette smoking saturates brain alpha 4 beta 2 nicotinic acetylcholine receptors. Arch Gen Psychiatry 63:907915

Brody AL, Mandelkern MA, Olmstead RE, Scheibal D, Hahn E, Shiraga S, Zamora-Paja E, Farahi J, Saxena S, London ED, McCracken JT (2006b) Gene variants of brain dopamine pathways and smoking- 
induced dopamine release in the ventral caudate/nucleus accumbens. Arch Gen Psychiatry 63:808-816

Brody AL, Mandelkern MA, Costello MR, Abrams AL, Scheibal D, Farahi J, London ED, Olmstead RE, Rose JE, Mukhin AG (2009a) Brain nicotinic acetylcholine receptor occupancy: effect of smoking a denicotinized cigarette. Int J Neuropsychopharmacol 12: 305-316

Brody AL, Mandelkern MA, Olmstead RE, Allen-Martinez Z, Scheibal D, Abrams AL, Costello MR, Farahi J, Saxena S, Monterosso J, London ED (2009b) Ventral striatal dopamine release in response to smoking a regular vs a denicotinized cigarette. Neuropsychopharmacology 34:282-289

Brody AL, London ED, Olmstead RE, Allen-Martinez Z, Shulenberger S, Costello MR, Abrams AL, Scheibal D, Farahi J, Shoptaw S, Mandelkern MA (2010) Smoking-induced change in intrasynaptic dopamine concentration: effect of treatment for tobacco dependence. Psychiatry Res Neuroimaging 183:218-224

Brody AL, Mandelkern MA, London ED, Khan A, Kozman D, Costello MR, Vellios EE, Archie MM, Bascom R, Mukhin AG (2011) Effect of secondhand smoke on occupancy of nicotinic acetylcholine receptors in brain. Arch Gen Psychiatry 68:953-960

Brody AL, Mukhin AG, Stephanie S, Mamoun MS, Kozman M, Phuong J, Neary M, Luu T, Mandelkern MA (2013) Treatment for tobacco dependence: effect on brain nicotinic acetylcholine receptor density. Neuropsychopharmacology 38:1548-1556

Brody AL, Mukhin AG, Mamoun MS, Luu T, Neary M, Liang L, Shieh J, Sugar CA, Rose JE, Mandelkern MA (2014) Brain nicotinic acetylcholine receptor availability and response to smoking cessation treatment: a randomized trial. JAMA Psychiatry 71:797-805

Brown AK, Mandelkern MA, Farahi J, Robertson C, Ghahremani DG, Sumerel B, Moallem N, London ED (2012) Sex differences in striatal dopamine D2/D3 receptor availability in smokers and nonsmokers. Int J Neuropsychopharmacol 15:989-994

Busto UE, Redden L, Mayberg H, Kapur S, Houle S, Zawertailo LA (2009) Dopaminergic activity in depressed smokers: a positron emission tomography study. Synapse 63:681-689

Cosgrove KP, Batis J, Bois F, Maciejewski PK, Esterlis I, Kloczynski T, Stiklus S, Krishnan-Sarin S, O'Malley S, Perry E, Tamagnan G, Seibyl JP, Staley JK (2009a) beta2-nicotinic acetylcholine receptor availability during acute and prolonged abstinence from tobacco smoking. Arch Gen Psychiatry 66:666-676

Cosgrove KP, Krantzler E, Frohlich EB, Stiklus S, Pittman B, Tamagnan GD, Baldwin RM, Bois F, Seibyl JP, Krystal JH, O'Malley SS, Staley JK (2009b) Dopamine and serotonin transporter availability during acute alcohol withdrawal: effects of comorbid tobacco smoking. Neuropsychopharmacology 34:2218-2226

Cosgrove KP, Esterlis I, McKee SA, Bois F, Seibyl JP, Mazure CM, Krishnan-Sarin S, Staley JK, Picciotto MR, O’Malley SS (2012) Sex differences in availability of beta2*-nicotinic acetylcholine receptors in recently abstinent tobacco smokers. Arch Gen Psychiatry 69:418-427

Cosgrove KP, Wang S, Kim SJ, McGovern E, Nabulsi N, Gao H, Labaree D, Tagare HD, Sullivan JM, Morris ED (2014) Sex differences in the brain's dopamine signature of cigarette smoking. J Neurosci 34: $16851-16855$

Cosgrove KP, Esterlis I, Sandiego C, Petrulli R, Morris ED (2015) Imaging tobacco smoking with PET and SPECT. Curr Top Behav Neurosci 24:1-17

Court JA, Lloyd S, Thomas N, Piggott MA, Marshall EF, Morris CM, Lamb H, Perry RH, Johnson M, Perry EK (1998) Dopamine and nicotinic receptor binding and the levels of dopamine and homovanillic acid in human brain related to tobacco use. Neuroscience 87:63-78

Dagher A, Bleicher C, Aston JAD, Gunn RN, Clarke PBS, Cumming P (2001) Reduced dopamine D1 receptor binding in the ventral striatum of cigarette smokers. Synapse 42:48-53
Dahoun T, Pardinas AF, Veronese M, Bloomfield MAP, Jauhar S, Bonoldi I, Froudist-Walsh S, Nosarti C, Korth C, Hennah W, Walters J, Prata D, Howes OD (2018) The effect of the DISC1 Ser704Cys polymorphism on striatal dopamine synthesis capacity: an [18F]-DOPA PET study. Hum Mol Genet 27:3498-3506

Damsma G, Westerink BH, de Vries JB, Horn AS (1988) The effect of systemically applied cholinergic drugs on the striatal release of dopamine and its metabolites, as determined by automated brain dialysis in conscious rats. Neurosci Lett 89:349-354

Danielson K, Putt F, Truman P, Kivell BM (2014) The effects of nicotine and tobacco particulate matter on dopamine uptake in the rat brain. Synapse (New York, N.Y.) 68:45-60

de Win MM, Habraken JB, Reneman L, van den Brink W, den Heeten GJ, Booij J (2005) Validation of [(123)I]beta-CIT SPECT to assess serotonin transporters in vivo in humans: a double-blind, placebo-controlled, crossover study with the selective serotonin reuptake inhibitor citalopram. Neuropsychopharmacology 30:996-1005

Di Chiara G, Bassareo V (2007) Reward system and addiction: what dopamine does and doesn't do. Curr Opin Pharmacol 7:69-76

Di Chiara G, Imperato A (1988) Drugs abused by humans preferentially increase synaptic dopamine concentrations in the mesolimbic system of freely moving rats. Proc Natl Acad Sci U S A 85:5274-5278

Domino EF, Evans CL, Ni L, Guthrie SK, Koeppe RA, Zubieta JK (2012) Tobacco smoking produces greater striatal dopamine release in Gallele carriers with mu opioid receptor A118G polymorphism. Prog Neuro-Psychopharmacol Biol Psychiatry 38:236-240

Domino EF, Ni L, Domino JS, Yang W, Evans C, Guthrie S, Wang H, Koeppe RA, Zubieta JK (2013) Denicotinized versus average nicotine tobacco cigarette smoking differentially releases striatal dopamine. Nicotine Tob Res 15:11-21

Dresel SH, Kung MP, Huang X, Plossl K, Hou C, Shiue CY, Karp J, Kung HF (1999) In vivo imaging of serotonin transporters with [99mTc]TRODAT-1 in nonhuman primates. Eur J Nucl Med 26: 342-347

Dubroff JG, Doot RK, Falcone M, Schnoll RA, Ray R, Tyndale RF, Brody AL, Hou C, Schmitz A, Lerman C (2015) Decreased nicotinic receptor availability in smokers with slow rates of nicotine metabolism. J Nucl Med 56:1724-1729

Egerton A, Mehta MA, Montgomery AJ, Lappin JM, Howes OD, Reeves SJ, Cunningham VJ, Grasby PM (2009) The dopaminergic basis of human behaviors: a review of molecular imaging studies. Neurosci Biobehav Rev 33:1109-1132

Egerton A, Demjaha A, McGuire P, Mehta MA, Howes OD (2010) The test-retest reliability of $18 \mathrm{~F}$-DOPA PET in assessing striatal and extrastriatal presynaptic dopaminergic function. NeuroImage 50: $524-531$

Faraone SV, Spencer TJ, Madras BK, Zhang-James Y, Biederman J (2014) Functional effects of dopamine transporter gene genotypes on in vivo dopamine transporter functioning: a meta-analysis. Mol Psychiatry 19:880-889

Gaddnas H, Pietila K, Piepponen TP, Ahtee L (2001) Enhanced motor activity and brain dopamine turnover in mice during long-term nicotine administration in the drinking water. Pharmacol Biochem Behav 70:497-503

Goodchild M, Nargis N, Tursan d'Espaignet E (2018) Global economic cost of smoking-attributable diseases. Tob Control 27:58-64

Heinz A, Goldman D, Jones DW, Palmour R, Hommer D, Gorey JG, Lee KS, Linnoila M, Weinberger DR (2000) Genotype influences in vivo dopamine transporter availability in human striatum. Neuropsychopharmacology 22:133-139

Howes OD, Kambeitz J, Kim E, Stahl D, Slifstein M, Abi-Dargham A, Kapur S (2012) The nature of dopamine dysfunction in schizophrenia and what this means for treatment. Arch Gen Psychiatry 69:776786

Huang CL, Chen HC, Huang NK, Yang DM, Kao LS, Chen JC, Lai HL, Chern Y (1999) Modulation of dopamine transporter activity by 
nicotinic acetylcholine receptors and membrane depolarization in rat pheochromocytoma PC12 cells. J Neurochem 72:2437-2444

Kambeitz J, Abi-Dargham A, Kapur S, Howes OD (2014) Alterations in cortical and extrastriatal subcortical dopamine function in schizophrenia: systematic review and meta-analysis of imaging studies. Br J Psychiatry J Ment Sci 204:420-429

Keiflin R, Janak PH (2015) Dopamine prediction errors in reward learning and addiction: from theory to neural circuitry. Neuron 88:247263

Kim E, Howes OD, Kapur S (2013) Molecular imaging as a guide for the treatment of central nervous system disorders. Dialogues Clin Neurosci 15:315-328

Kirch DG, Taylor TR, Creese I, Xu SX, Wyatt RJ (1992) Effect of chronic nicotine treatment and withdrawal on rat striatal D1 and D2 dopamine receptors. J Pharm Pharmacol 44:89-92

Kung MP, Essman WD, Frederick D, Meegalla S, Goodman M, Mu M, Lucki I, Kung HF (1995) IPT: a novel iodinated ligand for the CNS dopamine transporter. Synapse (New York, N.Y.) 20:316-324

Laruelle M, Abi-Dargham A, van Dyck CH, Rosenblatt W, Zea-Ponce Y, Zoghbi SS, Baldwin RM, Charney DS, Hoffer PB, Kung HF et al (1995) SPECT imaging of striatal dopamine release after amphetamine challenge. J Nucl Med 36:1182-1190

Le Foil B, Guranda M, Wilson AA, Houle S, Rusjan PM, Wing VC, Zawertailo L, Busto U, Selby P, Brody AL, George TP, Boileau I (2014) Elevation of dopamine induced by cigarette smoking: novel insights from a [11C]-(+)-PHNO PET study in humans. [references]. Neuropsychopharmacology 39:415-424

Le Foll B, Guranda M, Wilson AA, Houle S, Rusjan PM, Wing VC, Zawertailo L, Busto U, Selby P, Brody AL, George TP, Boileau I (2014) Elevation of dopamine induced by cigarette smoking: novel insights from a [11C]-+-PHNO PET study in humans. Neuropsychopharmacology 39:415-424

Leroy C, Karila L, Martinot JL, Lukasiewicz M, Duchesnay E, Comtat C, Dolle F, Benyamina A, Artiges E, Ribeiro MJ, Reynaud M, Trichard C (2012) Striatal and extrastriatal dopamine transporter in cannabis and tobacco addiction: a high-resolution PET study. Addict Biol 17: 981-990

Lin CY, Yeh CH, Chang TT, Kao CH, Tsai SY (2012) Smoking, dopamine transporter, and hand tremor. Clin Nucl Med 37:35-38

Lotfipour S, Mandelkern M, Alvarez-Estrada M, Brody AL (2012) A single administration of low-dose varenicline saturates alpha4beta2* nicotinic acetylcholine receptors in the human brain. Neuropsychopharmacology 37:1738-1748

Marshall DL, Redfern PH, Wonnacott S (1997) Presynaptic nicotinic modulation of dopamine release in the three ascending pathways studied by in vivo microdialysis: comparison of naive and chronic nicotine-treated rats. J Neurochem 68:1511-1519

Marubio LM, Gardier AM, Durier S, David D, Klink R, Arroyo-Jimenez MM, McIntosh JM, Rossi F, Champtiaux N, Zoli M, Changeux JP (2003) Effects of nicotine in the dopaminergic system of mice lacking the alpha4 subunit of neuronal nicotinic acetylcholine receptors. Eur J Neurosci 17:1329-1337

McCallum SE, Cowe MA, Lewis SW, Glick SD (2012) alpha3beta4 nicotinic acetylcholine receptors in the medial habenula modulate the mesolimbic dopaminergic response to acute nicotine in vivo. Neuropharmacology 63:434-440

McGranahan TM, Patzlaff NE, Grady SR, Heinemann SF, Booker TK (2011) alpha4beta2 nicotinic acetylcholine receptors on dopaminergic neurons mediate nicotine reward and anxiety relief. J Neurosci 31:10891-10902

Mifsud JC, Hernandez L, Hoebel BG (1989) Nicotine infused into the nucleus accumbens increases synaptic dopamine as measured by in vivo microdialysis. Brain Res 478:365-367

Montgomery AJ, Lingford-Hughes AR, Egerton A, Nutt DJ, Grasby PM (2007) The effect of nicotine on striatal dopamine release in man: A [11C]raclopride PET study. Synapse 61:637-645
Newberg A, Lerman C, Wintering N, Ploessl K, Mozley PD (2007) Dopamine transporter binding in smokers and nonsmokers. Clin Nucl Med 32:452-455

Nutt DJ, Lingford-Hughes A, Erritzoe D, Stokes PR (2015) The dopamine theory of addiction: 40 years of highs and lows. Nat Rev Neurosci 16:305-312

Okita K, Petersen N, Robertson CL, Dean AC, Mandelkern MA, London ED (2016) Sex differences in midbrain dopamine D2-type receptor availability and association with nicotine dependence. Neuropsychopharmacology 41:2913-2919

Owens MJ, Morgan WN, Plott SJ, Nemeroff CB (1997) Neurotransmitter receptor and transporter binding profile of antidepressants and their metabolites. J Pharmacol Exp Ther 283:1305-1322

Picciotto MR, Zoli M, Changeux JP (1999) Use of knock-out mice to determine the molecular basis for the actions of nicotine. Nicotine Tob Res 1(Suppl 2):S121-S125 discussion S139-140

Rademacher L, Prinz S, Winz O, Henkel K, Dietrich CA, Schmaljohann J, Mohammadkhani Shali S, Schabram I, Stoppe C, Cumming P, Hilgers RD, Kumakura Y, Coburn M, Mottaghy FM, Grunder G, Vernaleken I (2016) Effects of smoking cessation on presynaptic dopamine function of addicted male smokers. Biol Psychiatry 80: 198-206

Rasmussen K, Czachura JF (1995) Nicotine withdrawal leads to increased firing rates of midbrain dopamine neurons. Neuroreport 7 : 329-332

Salokangas RK, Vilkman H, Ilonen T, Taiminen T, Bergman J, Haaparanta M, Solin O, Alanen A, Syvalahti E, Hietala J (2000) High levels of dopamine activity in the basal ganglia of cigarette smokers. Am J Psychiatr 157:632-634

Scott DJ, Domino EF, Heitzeg MM, Koeppe RA, Ni L, Guthrie S, Zubieta J-K (2007a) Smoking modulation of micro-opioid and dopamine D2 receptor-mediated neurotransmission in humans. Neuropsychopharmacology 32:450-457

Scott DJ, Domino EF, Heitzeg MM, Koeppe RA, Ni L, Guthrie S, Zubieta JK (2007b) Smoking modulation of mu-opioid and dopamine D2 receptor-mediated neurotransmission in humans. Neuropsychopharmacology 32:450-457

Staley JK, Krishnan-Sarin S, Zoghbi S, Tamagnan G, Fujita M, Seibyl JP, Maciejewski PK, O'Malley S, Innis RB (2001) Sex differences in [123I]beta-CIT SPECT measures of dopamine and serotonin transporter availability in healthy smokers and nonsmokers. Synapse 41 : 275-284

Staley JK, Krishnan-Sarin S, Cosgrove KP, Krantzler E, Frohlich E, Perry E, Dubin JA, Estok K, Brenner E, Baldwin RM, Tamagnan GD, Seibyl JP, Jatlow P, Picciotto MR, London ED, O'Malley S, van Dyck CH (2006) Human tobacco smokers in early abstinence have higher levels of beta2* nicotinic acetylcholine receptors than nonsmokers. J Neurosci 26:8707-8714

Stengler-Wenzke K, Muller U, Barthel H, Angermeyer MC, Sabri O, Hesse S (2006) Serotonin transporter imaging with [123I]beta-CIT SPECT before and after one year of citalopram treatment of obsessive-compulsive disorder. Neuropsychobiology 53:40-45

Takahashi H, Fujimura Y, Hayashi M, Takano H, Kato M, Okubo Y, Kanno I, Ito H, Suhara T (2008) Enhanced dopamine release by nicotine in cigarette smokers: a double-blind, randomized, placebo-controlled pilot study. Int J Neuropsychopharmacol 11: 413-417

Thomsen G, Knudsen GM, Jensen PS, Ziebell M, Holst KK, Asenbaum S, Booij J, Darcourt J, Dickson JC, Kapucu OL, Nobili F, Sabri O, Sera T, Tatsch K, Tossici-Bolt L, van Laere K, Borght TV, Varrone A, Pagani M, Pinborg LH (2013) No difference in striatal dopamine transporter availability between active smokers, ex-smokers and non-smokers using $[<$ sup $>123</$ sup $>$ I]FP-CIT (DaTSCAN) and SPECT. EJNMMI Res 3:1-7 
VanNess SH, Owens MJ, Kilts CD (2005) The variable number of tandem repeats element in DAT1 regulates in vitro dopamine transporter density. BMC Genet 6:55

Volkow ND, Morales M (2015) The brain on drugs: from reward to addiction. Cell 162:712-725

Watkins SS, Koob GF, Markou A (2000) Neural mechanisms underlying nicotine addiction: acute positive reinforcement and withdrawal. Nicotine Tob Res 2:19-37

Weinstein AM, Freedman N, Greif J, Yemini Z, Mishani E, London E, Chisin R, Bocher M (2016) Negative association of pretreatment cigarette use with smoking-induced striatal dopamine release in smokers receiving bupropion treatment. Am J Addict 25:486-492

Wiers CE, Cabrera EA, Tomasi D, Wong CT, Demiral SB, Kim SW, Wang GJ, Volkow ND (2017) Striatal dopamine D2/D3 receptor availability varies across smoking status. Neuropsychopharmacology 42:2325-2332

Willuhn I, Burgeno LM, Groblewski PA, Phillips PE (2014) Excessive cocaine use results from decreased phasic dopamine signaling in the striatum. Nat Neurosci 17:704-709

Wing VC, Payer DE, Houle S, George TP, Boileau I (2015) Measuring cigarette smoking-induced cortical dopamine release: a [11C]FLB457 PET study. [references]. Neuropsychopharmacology 40:14171427
Yang YK, Yao WJ, McEvoy JP, Chu CL, Lee IH, Chen PS, Yeh TL, Chiu NT (2006) Striatal dopamine D2/D3 receptor availability in male smokers. Psychiatry Res 146:87-90

Yang YK, Yao WJ, Yeh TL, Lee IH, Chen PS, Lu RB, Chiu NT (2008) Decreased dopamine transporter availability in male smokers - a dual isotope SPECT study. Prog Neuro-Psychopharmacol Biol Psychiatry 32:274-279

Yasuno F, Ota M, Ando K, Ando T, Maeda J, Ichimiya T, Takano A, Doronbekov TK, Fujimura Y, Nozaki S, Suhara T (2007) Role of ventral striatal dopamine D1 receptor in cigarette craving. Biol Psychiatry 61:1252-1259

Zhang L, Doyon WM, Clark JJ, Phillips PE, Dani JA (2009) Controls of tonic and phasic dopamine transmission in the dorsal and ventral striatum. Mol Pharmacol 76:396-404

Zhang L, Dong Y, Doyon WM, Dani JA (2012) Withdrawal from chronic nicotine exposure alters dopamine signaling dynamics in the nucleus accumbens. Biol Psychiatry 71:184-191

Zhou FM, Liang Y, Dani JA (2001) Endogenous nicotinic cholinergic activity regulates dopamine release in the striatum. Nat Neurosci 4: $1224-1229$

Publisher's note Springer Nature remains neutral with regard to jurisdic tional claims in published maps and institutional affiliations. 